\title{
Biodiversity of Vegetation and Flora in Tropical Africa
}

\author{
Luís Catarino ${ }^{1, *(D)}$ and Maria M. Romeiras $1,2, *$ (D) \\ 1 Centre for Ecology, Evolution and Environmental Changes (cE3c), Faculty of Sciences (FCUL), \\ University of Lisbon, 1749-016 Lisbon, Portugal \\ 2 Linking Landscape, Environment, Agriculture and Food (LEAF), School of Agriculture (ISA), \\ University of Lisbon, 1349-017 Lisbon, Portugal \\ * Correspondence: lmcatarino@fc.ul.pt (L.C.); mmromeiras@isa.ulisboa.pt (M.M.R.)
}

Received: 24 September 2020; Accepted: 24 September 2020; Published: 25 September 2020

\begin{abstract}
African ecosystems comprise a wealthy repository of biodiversity with a high proportion of native and endemic plant species, which makes them biologically unique and providers of a wide range of ecosystem services. A large part of African populations, in both rural and urban areas, depends on plants for their survival and welfare, but many ecosystems are being degraded, mostly due to the growing impacts of climate change and other anthropogenic actions and environmental problems. Loss of habitat and biodiversity affects livelihoods, water supply and food security, and reduces the resilience of ecosystems in the African continent. Knowledge of the huge African plant and ecosystem diversity, and on the structure, composition and processes involved in vegetation dynamics, is crucial to promote their sustainable use and to preserve one of the most understudied regions in the world. This Special Issue aimed to gather contributions that update and improve such knowledge.
\end{abstract}

Keywords: flora; vegetation; Africa; tropical biodiversity

African biodiversity has been declining over the last decades, with losses of species and habitats. According to UNEP-WCMC [1], ongoing loss of biodiversity in Africa is driven by a combination of human-induced factors that result in deforestation and forest degradation, entailing important land-cover changes. Moreover, the negative impacts of climate change on species and ecosystems are exacerbating the effects of such pressures. Different figures have been published, but the most optimistic calculations indicate a forest loss of $22 \%$ across tropical Africa since 1900, whereas the most pessimistic estimates point to $35-55 \%$, to which the large-scale forest degradation must be added [2]. Consequently, as much as one-third of the tropical African flora is potentially threatened with extinction [3].

The contributions to this Special Issue of Diversity deal with a range of subjects on African plant and vegetation biology and ecology, both in continental and insular regions. Two main broad subjects are addressed: structure, ecology and composition of African vegetation, and species diversity and conservation.

Among those on the first broad topic, Abiem et al. [4] present a study on forest diversity and distribution of tree species in a grassland-forest transition, a typical ecotone across the continent. The diversity and structure of miombo, one of the most important ecoregions in the continent, is studied in southwest Angola by Godlee et al. [5] and compared to other miombo sub-types. In a work concerning the Cabo Verde Islands (West Africa), Neto et al. [6] discuss the role of abiotic factors, particularly climate and topography, in shaping the diversity of plant communities in this semi-arid archipelago. Hammond and Pokorný [7] address the process of succession in a tropical moist semi-deciduous forest, analyzing the diversity of tree species in gap regeneration. The important issue of fire effect on natural vegetation and its implications is presented for Angola by Catarino et al. [8], who analyzed the 
spatial and temporal trends of burnt areas and found increasing trends associated with savannas and grasslands in miombo woodlands' biome.

Aspects of species diversity and conservation are addressed, among others, by Brée et al. [9], who analyzed the process of species diversification in African rainforests for two restricted clades of Annonaceae, an important family in African forests. The subject of conservation through cultivation of widely used wild species was examined by Mofokeng et al. [10] with a case study on Hypoxis hemerocallidea. With an innovative perspective, a phylogenomic study of the Acanthaceae genus Monechma, which occurs in savanna and succulent biomes, is also included. In this study, Darbyshire et al. [11] found divergent plant lineages with ecological importance, and set clues for future research towards understanding the biogeographical history of continental Africa.

The guest editors of this Special Issue of Diversity journal hope that the set of works here gathered will contribute to enhancing knowledge and improving conservation actions concerning the flora and vegetation of tropical Africa.

Funding: The authors are grateful to the Foundation for Science and Technology (FCT, Portugal) for financial support through national funds FCT/MCTES to Centre for Ecology, Evolution and Environmental Changes (cE3c: UIDB/00239/2020), and Linking Landscape, Environment, Agriculture and Food (LEAF: UID/AGR/04129/2020). Also, M.M.R. would like to acknowledge the support provided by FCT and Aga Khan Development Network (AKDN) under the project CVAgrobiodiversity/333111699.

Conflicts of Interest: The authors declare no conflict of interest.

\section{References}

1. UNEP-WCMC. The State of Biodiversity in Africa: A mid-term review of progress towards the Aichi Biodiversity Targets; UNEP-WCMC: Cambridge, UK, 2016; ISBN 978-92-807-3508-6.

2. Aleman, J.C.; Jarzyna, M.A.; Staver, A.C. Forest extent and deforestation in tropical Africa since 1900. Nat. Ecol. Evol. 2017, 2, 26-33. [CrossRef] [PubMed]

3. Stévart, T.; Dauby, G.; Lowry, P.P.; Blach-Overgaard, A.; Droissart, V.; Harris, D.J.; Mackinder, B.A.; Schatz, G.E.; Sonké, B.; Sosef, M.S.M.; et al. A third of the tropical African flora is potentially threatened with extinction. Sci. Adv. 2019, 5, eaax9444. [CrossRef] [PubMed]

4. Abiem, I.; Arellano, G.; Kenfack, D.; Chapman, H.M. Afromontane Forest Diversity and the Role of Grassland-Forest Transition in Tree Species Distribution. Diversity 2020, 12, 30. [CrossRef]

5. Godlee, J.L.; Gonçalves, F.M.; Tchamba, J.J.; Chisingui, A.V.; Muledi, J.I.; Shutcha, M.N.; Ryan, C.; Brade, T.K.; Dexter, K.G. Diversity and Structure of an Arid Woodland in Southwest Angola, with Comparison to the Wider Miombo Ecoregion. Diversity 2020, 12, 140. [CrossRef]

6. Neto, C.; Costa, J.C.; Figueiredo, A.; Capelo, J.H.; Gomes, I.; Silva, S.; Semedo, J.M.; Lopes, A.; Dinis, H.; Correia, E.; et al. The Role of Climate and Topography in Shaping the Diversity of Plant Communities in Cabo Verde Islands. Diversity 2020, 12, 80. [CrossRef]

7. Hammond, M.E.; Pokorný, R. Diversity of Tree Species in Gap Regeneration under Tropical Moist Semi-Deciduous Forest: An Example from Bia Tano Forest Reserve. Diversity 2020, 12, 301. [CrossRef]

8. Catarino, S.; Romeiras, M.M.; Figueira, R.; Aubard, V.; Silva, J.; Pereira, J.M.C. Spatial and Temporal Trends of Burnt Area in Angola: Implications for Natural Vegetation and Protected Area Management. Diversity 2020, 12, 307. [CrossRef]

9. Brée, B.; Helmstetter, A.J.; Bethune, K.; Ghogue, J.-P.; Sonké, B.; Couvreur, T.L. Diversification of African Rainforest Restricted Clades: Piptostigmateae and Annickieae (Annonaceae). Diversity 2020, 12, 227. [CrossRef] 
10. Mofokeng, M.M.; Araya, H.T.; Van Staden, J.; Sehlola, D.; Du Plooy, C.P.; Bairu, M.W.; Venter, S.; Mashela, P.W. Diversity and Conservation through Cultivation of Hypoxis in Africa-A Case Study of Hypoxis hemerocallidea. Diversity 2020, 12, 122. [CrossRef]

11. Darbyshire, I.; Kiel, C.A.; Astroth, C.M.; Dexter, K.G.; Chase, F.M.; Tripp, E.A. Phylogenomic Study of Monechma Reveals Two Divergent Plant Lineages of Ecological Importance in the African Savanna and Succulent Biomes. Diversity 2020, 12, 237. [CrossRef]

(C) 2020 by the authors. Licensee MDPI, Basel, Switzerland. This article is an open access article distributed under the terms and conditions of the Creative Commons Attribution (CC BY) license (http://creativecommons.org/licenses/by/4.0/). 